\title{
Peningkatan Human Capital Dalam Proses Pembelajaran di Era New Normal
}

\author{
Novira Arafah (1) \\ Syamsul Bahri ${ }^{(2)}$ \\ Institut Pesantren KH. Abdul Chalim Mojokerto ${ }^{(1,2)}$ \\ novira.arafah2121@gmail.coms ${ }^{(1)}$ \\ syamsulbahriabdullah@gmail.com ${ }^{(2)}$
}

\begin{abstract}
This literature study was conducted to find out: Analysis of Human Resource Management in Improving Strategies Learrning in the New Normal Era. In this research, the method used qualitative with a library research. The results of the study indicate are: Human Resource management in improving strategies learrning in the new normal era is effort, mature readiness, provisioning both in terms of IT skills and virtual learning progress. The most appropriate learning strategy in the new normal era is to follow the rules of the Ministry of Education and Culture with virtual learning through agreed platforms. For this reason, the 2 main elements of teaching and learning activities take place, these students and teachers must be equipped, qualified and know the direction of learning that will be filtered in order to minimize misunderstanding between teacher and students. While students at home, study is assisted and supervised by their parents to avoid deception, laziness and cheating during the exam. So that ethics, values / norms remain upheld in the world of academia.
\end{abstract}

Keywords : Analysis of Human Resource Management; Strategies Learrning in the New Normal Era

\begin{abstract}
ABSTRAK
Studi pustaka ini dilakukan untuk mengetahui: Analisis Manajemen Sdm Dalam Meningkatkan Strategi Pembelajaran Di Era New Normal. Dalam penelitian ini, metode yang digunakan ialah kualitatif dengan pendekatan studi kepustakaan (library research). Hasil dari penelitian menunjukkan bahwa : Manajemen SDM dalam meningkatkan strategi pembelajaran di era new normal adalah dengan upaya, kesiapan matang, pembekalan baik dari segi kecakapan TI dan keterbiasaan berlangsungnya virtual learnig. Strategi pembelajaran yang paling tepat dalam era new normal ini ialah mengikuti aturan Kemendikbud dengan pembelajaran virtual melalui platform-platform yang telah disepakati. Untuk itu 2 elemen pokok berlangsung kegiatan belajar-mengajar, siswa dan guru ini harus dibekali, mumpuni dan tau arah belajar yang akan filterisasi agar meminimalisir kesalahanpahaman antara guru dan siswa. Sementara siswa, di rumah, belajar dibantu dan diawasi oleh orangtuanya agar tidak terjadi tipu daya, kemalasan dan kecurangan saat pelaksanaan ujian. Sehingga etika, nilai/norma tetap dijunjung tinggi dalam dunia akademisi.
\end{abstract}

\section{Kata Kunci : Analisis Manajemen Sumber Daya Manusia; Strategi Pembelajaran Era New Normal}




\section{PENDAHULUAN}

Secara sadar, kita mengetahui bahwasannya maanajemen sumber daya manusia merupakan bagian inti/pokok dalam suatu asosiasi ataupun naungan lembaga pendidikan. Tak luput dalam ini, bagaimana sumber daya manusia itu sendiri mendedikasikan diri untuk menyambut masa beralihnya normal (seperti sedia kala) menjadi pandemi (sebab telah menimpa puluhan Negara di dunia) menjadi new normal (normal dengan gaya baru). Mengapa dipilih era new normal bukan normal semula ? Sebab dalam masa ini kita telah dituntut untuk siap, setelah beberapa bulan menahan diri layaknya proses berpuasa dari yang namanya keluar rumah unutk hal yang tidak dibutuhkan. Bahkan sebagian orang diharuskan untun berdiam diri hingga waktu yang belum ditentukan sebagai bentuk ikhtiar atas pandemi yang memungkinkan menimpa yang tak pilah-pilih/kenal siapapun. Hampir lebih dari 3 bulan baik instatnsi pemerintahan, pendidikan dan elemen yang kira-kira membutuhaan terlalu banyak kontak fisik harus dihentikan sementara waktu guna mengikuti aturan jaga jarak (phsycal distancing) untuk mencegah virus yang cepat berkembang ini menyebar. Menyangkut dunia pendidikan,, dimana anak-anak libur lebih lama dari biasanya, bahkan berdasarkan kacamata yang dilihat sekarang, kebosanan dan kejenuhan mulai menghias diri seperti dalih yang merindukan, guru, teman sebayanya, pelajaran disekolah dan aktivitas yang biasanya ia jalani. Memang, lembaga pendidikan juga mengikuti alur yang cepat tanggap sehingga tetap mengadakan pembelajaran yang difungsikan dengan daring method.

Strategi pembelajaran mengacu era new normal dipandu dengan mengikuti protokol kesehatan dan memicu guru sebagai bagian dari SDM terpenting dalam kegiatan belajarmengajar untuk mempunyai jurus jitu mengelola belajar tanpa tatap muka disertai tidak menghilangkan learning essention itu sendiri. Seperti yang beredar di media social saat ini, guru kerap kali memberikan contoh lalu membagian link dan meminta siswa mengikutinya dirumah merupakan cara efisien yang ditempuh untuk belajar di tengah pandemi dengan new normal era.

Tetapi ketidakefektifan baik dari SDM dalam hal ini pendidik, murid maupun orang tua menemukan berbagai kendala dengan metode virtual yang diterapkan pada perabadan baru kehidupan manusia ini. Olehnya, SDM haruslah terbiasa dengan dayanya untuk meningkatkan dengan berinovasi dengan strategi-strategi baru guna kelancaran KBM dengan era yang saat ini tengah dijalani. Para ahli juga telah jauh-jauh gari meneliti sehingga penemuannya sebagaimana berikut yang dikemukakan oleh Ni'mah bahwa : ada juga kendala dari E- learning ini, yaitu : 1. Listrik bisa padam ketika sedang menakses program pembelajaran 2. Jaringan 
internet yang buruk 3. Komitmen dari orangtua yang tidak menentu 4. Mahasiswa/siswa yang sulit belajar dengan cara ini 5. Kesalahpahaman antara dosen/guru dan maha/siswa 6 . Ketidaktahuan IPTEK (Rizqulloh, 2020, p. 3)

\section{METODE PENELITIAN}

Studi yang dilakukan ini merupakan sebuah studi literatur (literature review) yaitu sebuah pencarian dan merangkum beberapa literatur empiris yang sesuai dan relevan dengan tema. Literatur yang digunakan berupa buku, artikel ilmiah yang berasal dari jurnal internasional maupun nasional. Literatur yang digunakan adalah literatur relevan dengan studi ini dan telah dicetak maupun dipublikasikan. Penggunaan kriteria inklusi dan eksklusi terhadap seluruh literatur merupakan metode penyeleksiannya.

\section{HASIL PENELITIAN DAN PEMBAHASAN}

\section{Manajemen Sumber Daya Manusia}

Manajemen sumber daya manusia bukanlah suatu tujuan dan akhir suatu proses, melainkan suatu perangkat atau alat untuk membantu tercapainya suatu tujuan secara keseluruhan. Untuk itu, satu bagian/unit manajemen sumber saya manusia di suatu lembaga diadakan untuk melayani bagian-bagian lain lembaga maupun organisasi. Manajemen Sumber Daya Manusia diartikan oleh Mangkunegara sebagai suatu pengolahan dan pendayagunaan sumber daya yang ada pada individu. Dalam arti lain merupakan suatu perencanaan, pengorganisasian, pelaksanaan pengawasan terhadap pengadaan, pengembangan, pemberian balas jasa, pengintegrasian, pemeliharaan dan pemisahaan tenaga kerja dalam rangka mencapai tujuan suatu lembaga.

Manajemen sumber daya manusia di setiap lembaga/organisasi haruslah sesuai dengan tujuan organisasi dengan tidak berlebihan ataupun tidak terlalu kurang. Sebab, adanya suatu kelebihan atau kekurangan penerapan sasaran di masing-masing unit lembaga menunjukkan adanya wasted atau pemborosan penggunaan sumber daya manusia. Maka dari itu setiap unit lembaga yang mengelola atau menggunakan sumber daya manusia harus mampu menjaga keseimbangan yang tepat antara kualitas dan kuantitas sumber dayanya masing-masing. Agar selaras dengan tujuan yang telah ditetapkan (Aprilianto, 2019).

Dengan kata lain, yang perlu dan utama di manajemen dalam hal ini ialah 3 komponen SDM, yaitu guru sebagai tenaga pendidik, murid selaku peserta didik dan orang utama sebagai pemangku kepentingan pendidikan. Serta keterkaitan untuk berpartisipasi antara masyarakat 
dan orang tua merupakan hal utama yang tak kalah pentingnya.

Menjalin kerja sama antara sekolah dengan masyarakat merupakan bentuk kegiatan yang dilakukan baik secara langsung maupun tidak. Misalnya bantuan dan dukungan dari pihak yang ada di lingkungan sekitar pendidikan. Walaupun, seluruh lapisan masyarakat belum sepenuhnya nyata dalam bersumbangsih, tetapi lembaga pendidikan harus terus ontimis dan gencar untuk melakukan sosialisasi dan aktivitas yang saling berkaitan untuk keoptimalan tujuan yang dicapai (Setiana, 2018). Sebagai bagian komponen mikro penentu dominan mutu pendidikan, guru haruslah bermutu dan berkinerja baik dalam globalisasi dengan barusaha menguasai berbagai teknologi informasi dan komunikasi. Sebab, kemajuan aspek informasi dan komunikasi mengalami perubahan yang dahsyat dalam era globalisasi. Dalam sistem pendidikan nasional guru memiliki peranan strategis pada proses pembelajaran secara khusus dan proses pendidikan secara keseluruhan (Kartiko, 2019).

Khususnya di tengah pandemik dan masa transisi new normal era saat ini. Penting sekali bagi 2 elemen pokok di atas saling sharing dan caring untuk dapat mengimbangi kondisi psikis anak yang tertekan dengan keterbatasan aktivitas yang memungkinkan berdampak stessor. Jadi, hal ini dapat dicegak melalui menimilisir kesenjangan dengan cara rutinitas yang tetap berjalan dengan pengawasan ekstra dari era normal sebelumnya.

\section{Cara-cara Penanganan Perubahan}

Pergeseran paradigma dalam mengelola organisasi di era unpredictable serta kompleks membuat organisasi untuk perlu melakukan penyesuaian melalui sebuah proses perubahan. Perubahan organisasi adalah usaha untuk mempertahankan kelangsungan hidup agar tetap survive menghadapi permasalahan yang tidak pasti seperti Covid-19. Organisasi-organisasi yang cepat beradaptasi dengan perubahan lingkungan adalah organisasi yang survive (Warsono, 2020, p. 6)

Ada 2 pendekatan utama penanganan perubahan organisasi yang dapat digunakan para manajer, seperti ditunjukkan pada gambar di bawah ini :

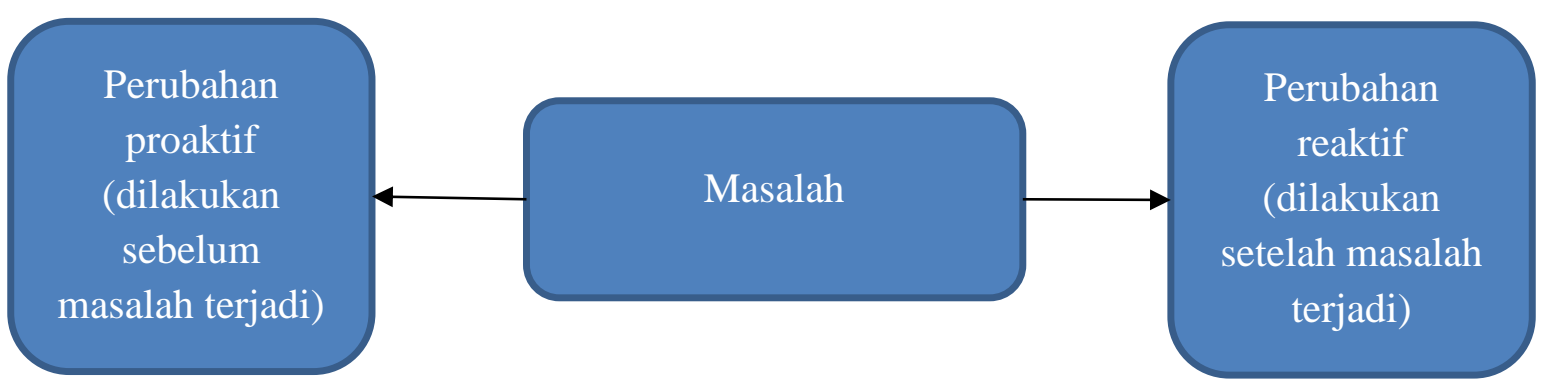


Pertama, adalah proses perubahan reaktif, dimana pemimpin beraksi atas tanda-tanda bahwa perubahan dibutuhkan, pelaksanaan modifikasi sedikit demi sedikit untuk menangani masalah-masalah tertentu yang timbul. Kedua, pemimpin mengembangkan suatu program perubahan yang direncanakan (planned change), yang sering disebut sebagai proses proaktif, melalui pelaksanan berbagai investasi waktu dan sumber daya lainnya yang berarti untuk mengubah cara-cara operasi lembaga/organisasi. Pendekatan pertama, lebih sederhana dan lebih murah dibanding pendekatan kedua. Diperlukan pemimpin dalam pemecahan masalah sederhana (kecil) dan penyesuaian hari ke hari yang integral dengan jabatannya.

Pendekatan kedua, program poerubahan yang ditrencanakan menyangkut kegiatankegiatan yang disengaja untuk mengubah status quo. Thimas dan Bennis mendefinisikan perubahan yang direncanakan sebagai perancangan dan implementasi inovasi struktural, kebijaksanaan atau tujuan baru, atau suatu perubahan dalam filsafat, iklim dan cara pengoperasian secara sengaja. Pendekatan ini tepat apabila keseluruhan lembaga/organisasi harus menyiapkan diri untuk atau menyesuaikan dengan perubahan (Handoko, 1991).

Hal ini dapat di lihat dari merebaknya pandemi yang terjadi dia dunia khususnya di Negara kita tercinta, Indonesia dengan khas lagu kebangsaannya Indonesia Raya. Relevansinya, kita memang benar-benar perlu mengadakan reaksi sesuai dengan pendekatan kedua dari pendapat ahli di atas. Sebab, pandemi ini tidak bias ditebak kapan berakhir secara tuntasnya. Wallahu'alam. Tugas kita sebagai akademisi ialah selalu melakukan ikhtiar dengan mempercayakan pada para ahli yaitu tim medis dan Dinas Pendidikan yang telah bersusah payah merancang atau merenovasi pembaruan pendidikan yang disesuaikan dengan era new normal yang sedang berangsur diterapkan di persebaran 34 provinsi Indonesia.

Salah satu upayanya ialah dengan active mengikuti Webinar di masa pandemi. Dari sini kita bias sharing secara langsung dengan tim perancang, penggas dan pembuat kebijakan di Indonesia walau dengan limited time yang ditentukan. Selaras dengan ungkapan Kemendikbud, Romi menuturkan dari akhir kesimpulan webinar yang diadakan pada Senin/07/07/2020 bahwa kita perlu saling mengisi, mengajari, sharing pengalaman dan kolaborasi. Serupa Miss Riska selaku pengelola lembaga pendidikan KAIZEN pada kesempatan ini pun mengemukakan pentingnya kolaborasi antara lingkungan sekolah dan lingkungan sekitar di tengah pandemi ini.

\section{Pengembangan Kemampuan SDM}

1. Pelayanan yang baik hanya akan dapat terwujud apabila manajemen SDM dilakukan dengan mengedepankan kepentingan pengguna jasa pendidikan (Winarsih, 2016). 
2. Komunikasi. Purwanto dalam bukunya mengemukakan komunikasi sebagai perantara dari penyampaian ideologi seseorang kepada orang lain pastinya memiliki kendala dan hambatan yang dapat memicu kesalahpahaman. Faktor-faktor penghambat komunikasi terdapat dalam beberapa hal antara lain "masalah dalam pengembangan pesan, masalah dalam penyampaian pesan, masalah dalam penerimaan pesan dan masalah dalam penafsiran pesan" (Muslih, 2020, p. 60). Sebagaimana Rizal pun mengungkapkan , omunikasi antara pendidik dan peserta didik berlangsung dua arah yang dijembatani oleh penggunaan media, seperti komputer, televisi, radio, telepon, internet, video, dan sebagainya (Ahmad, 2020, p. 209)

3. Jejaring global, tahapan ini dimulai dari pertengahan tahun 1990-an. Disebut dengan jejaring global karena perusahaan-perusahaan sudah dihubungkan dengan jaringan system teknologi informasi secara global dengan teknologi telekomunikasi melalui internet, yang juga popular dengan nama system teknologi informasi. Dengan hal lain dilakukan penekanan terhadap aplikasi informasi. (HM, 2017, p. 211).

4. Siklus PDCA (Plan, Do, Check dan Act) dan SDCA (Standardize, Do, Check, dan Act) Pakar ahli Edward Deming sebagai pengagas siklus ini, merupakan siklus unutk melakukan perbaikan proses continue dan pengendalian yang meliputi langkah sebagaimana gambar berikut:

\begin{tabular}{|c|c|c|c|}
\hline & & Siklus : & Langkah-langkah \\
\hline & & Plan & 1. Identifikasi maslah utama \\
\hline & & & 2. Meneliti penyebab utama \\
\hline Act & Plan & & 3. Menentukan penyebab \\
\hline Check & Do & & 4. Rencana \\
\hline & & sasaran & \\
\hline & & Do & 5. Tanggung jawab dan pelaksanaan \\
\hline & & rencana & \\
\hline
\end{tabular}

Check

6. Evaluasi dan validasi pelaksanaan

Act

7. Kaji semua feedback, lakukan perbaikan

8. Memperbaiki standar

Mula-mula perbaikan, setiap proses baru biasanya belum stabil. Sebelum 
melakukan perbaikan untuk siklus berikutnya, proses baru distabilkan melalui SDCA yang sifatnya sebagai pemeliharaan. Berikut gambar pemeliharaan SDCA:

\section{Pemeliharaan}

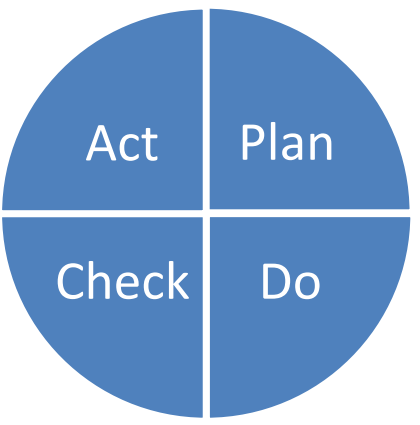

Ketika ketidakwajaran timbul dalam suatu proses baru, beberapa pertanyaan harus diajukan sebagai bahan koreksi, yaitu apakah hal tersebut terjadi karena tidak memiliki standar atau standar tidak dipatuhi, bias jadi kurang rinci atau tidak rinci. Setelah standar disempurnakan dan dipatuhi serta membawa kestabilan proses, akan diperkenankan beralih ke siklus PDCA selanjutnya. Hal ini menandakan diklus SDCA menerapkan standarisasi guna mencapai kestabilan proses yang berfungsi pemeliharaan, sementara siklus PDCA menerapkan fungsi perbaikan dan pengendalian (Nasution, 2015, p. 93).

Masa transisi ini benar-benar harus dipersiapkan, mulai dari pelayanan, komunikasi, jejaring gliobal dan siklus yang ditawarkan oleh Edward Deming di atas. Pelayanan yang ditinjau dari peradaban baru dimana virtual meeting adalah sarana yang telah ditempuh oleh satuan pendidikan kita saat ini dengan berbagai fitures aplikasi yang disediakan, yang paling dominan seperti: zoom, gooegle-meet,live in youtube, ruang guru, ruang belajar serta berbagai macam diskusi online lainnya yang telah digelar di dunia maya. Semua itu juga memiliki dampak dan kendala sebagaimana yang kita ketahui tidak semua anak didik/masyarakat Indonesia menggenggam gadget, akses signal yang kurang memadai untuk daerah pedalaman, kuota internet yang besar pemakaiannya di tengah minimnya penghasilan, serta seorang guru yang harus rela mendatangi siswanya ke rumah demi tetap mendapatkan pendidikan yang layak. Apresiasi sekaligus miris, sebab usaha yang sebegitu ekstra dan semboyan guru tanpa tanda jasa yang melekat padanya belum mencapai taraf maksimal dalam pelaksanaan di lapangan. 


\section{Menuju New Normal Transition}

Dalam realitas baru, yang belum pernah terjadi sebelumnya, pasca Covid 19 ini, dunia digemparkan dengan istilah new normal, yang membuat restrukturisasi (penataan kembali) kehidupan masyarakat, dan dalam waktu dekat, akan ada perdebatan dan diskusi tentang new normal (Kevin Sneader, Shubham Singhal 2020). Istilah "new normal” yang berarti normalitas atau kenormalan baru, sudah lama ada dan tidak asing. Langkah pemerintah menerapkan new normal sudah sangat tepat (Wahyudin Darmalaksana 2020). Adapun bagi civitas madrasah dan sekolah penting sekali meperhatikan langkah langkah tersebut menuju keberhasilan pelaksanaan new normal dengan tentunya memperhatikan prosedur (Wakhudin Dkk 2020).

Beragam istilah dalam memahami term tersebut, seperti tatanan kehidupan baru (kata bapak Joko Widodo), adaptasi kebiasaan baru (kata bapak Ridwan Kamil), transisi menyambut kenormalan baru (kata bapak Anies Baswedan dan bapak Bima Arya), dan penyesuaian pola hidup (kata wiku Asisasmita selaku ketua tim pakar gugus tugas percepatan covid-19. (Kurniadi 2020). Adapun kementrian pendidikan dan kebudayaan (kemendikbud) dalam akun resmi instagramnya menjelaskan bahwa kata new normal memiliki padanan kata dalam bahasa indonesia yaitu kenormalan baru yang merupakan keadaan normal yang baru yang belum pernah ada sebelumnya. (Albertus Adit 2020). Menurut juru bicara pemerintah dalam percepatan penanganan COVID 19, new normal dimaknai sebagai gerakan hidup baru, kehidupan yang produktif dan aman dari wabah virus corona. Achmad Yurianto mengatakan bahwa kita tidak mungkin kembali pada situasi sebagaimana sebelumnya (normal lama), oleh karena itu kita harus berubah. (Nefan Kristiono 2020).

Substansi dari new normal tidak boleh dianggap sebatas pelonggaran PSBB dan transportasi publik. Meskipun banyak yang terkejut, akhirnya dipahami sebagai sesuatu yang normal dan harus berjalan. Menurut Ridwan Sanjaya mengutip pendapat Paul Glover dalam philadelphia city paper 2009 bahwa dalam menjelaskan kondisi yang semula dinilai tidak umum menjadi sesuatu yang kemudian dianggap biasa, wajar, dan akhirnya diterima secara luas, new normal yang diterima oleh masyarakat tersebut menjadi hal yang kemudian dipahami sebagai kondisi yang wajar. Berbagai perubahan yang terus terjadi ini menciptakan kondisi yang disebut sebagai "the new normal". New normal ditanggapi beragam oleh masyarakat. Hal demikian adalah wajar, selama diniatkan untuk kehidupan yang lebih baik dan dilakukan berdasarkan kajian riset yang valid (Ridwan Sanjaya 2018).

WHO telah menetapkan beberapa barometer sebelum pemerintah menerapkan normal 
baru, antara lain: memastikan penularan terkendali, sistem kesehatan dalam keadaan baik, jaminan langkah pencegahan di lingkungan kerja, mencegah kasus impor covid, dan memastikan kesadaran dan partisipasi masyarakat. (Redaksi WE Online 2020). Sejalan dengan itu, pemerintah menentukan tiga standar pengurangan PSBB, yaitu dengan melihat penularan berdasarkan reproduction rate (R0), tingkat kapasitas sistem kesehatan dalam merespon pelayanan Covid-19 dan tingkat tes Covid-19 secara massal yang dilakukan. (Abdul Basith Bardan 2020).

Melihat dan mencermati standar dan baromater di atas, pakar epidemiologi Universitas Indonesia Pandu Riono, dikutip dari You Tube Kompas TV, Sabtu, 30 Mei 2020 menilai gerakan hidup baru (new normal) belum dapat terlaksana secara menyeluruh, jika parameter kesehatan belum terpenuhi, disebabkan ketelitian atau keautentikan data covid 19 sehingga sulit menghitung angka reproduction rate (RO). (Vintoko 2020). Menurut Jusuf Kalla, dikutip dari Akurat. Com, Sabtu, 30 Mei 2020, memprediksikan new normal akan berlangsung minimal 3 (tiga) tahun, jika sudah ditemukan vaksin covid 19 pada Februari 2021 dan selanjutnya ialah produksi vaksin secara massal pada Agustus dan September 2021. (Tim Jurnal Presisi 2020). Banyak negara yang memutuskan kembali pada gerakan hidup baru (new normal) seperti Tiongkok (China dan korea selatan namun tetap mengikuti protokol kesehatan. Tetapi akhirnya negara tersebut kembali berlakukan pembatasan sosial.

Fenomena di atas, sepaham dengan maklumat yang sering disampaikan oleh epidemiolog Universitas Indonesia Pandu Riono, dikutip dari Kompas, 29 Mei 2020:

"Jika tetap memaksakan diterapkannya fase normal baru, sementara persyaratan dan kriteria yang telah ditentukan belum terpenuhi, maka bersiap-siaplah menanggung peningkatan kasus". (CNN Indonesia 2020).

Berlandaskan paparan diatas, penulis berpandangan bahwa sebelum menetapkan kembali pada gerakan hidup baru (new normal), sebaiknya didahului tahap transisi, yaitu suatu tahap yang sangat menentukan berhasil tidaknya tahap new normal nantinya.

Ada dua tahap perubahan yang bisa di terapkan yaitu tahap pertama: tahap pemutusan, kemudian tahap kedua, tahap transisi, yakni suatu prosedur dimana keluar dari kebiasaan lama dan masuk ke kebiasaan baru atau dimulai dengan suatu pemutusan dan diakhiri dengan suatu permulaan. 


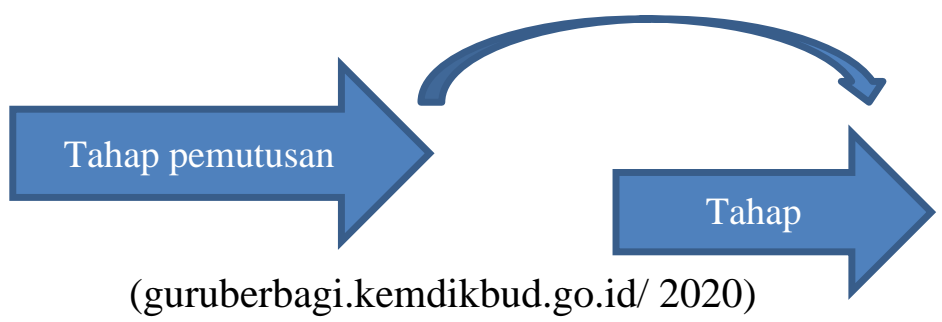

\section{Tahap New normal}

(guruberbagi.kemdikbud.go.id/2020)

Penulis melihat, kebanyakan belum berhasil melewati fase pertama, masyarakat belum disiplin mengikuti protokol kesehatan, konsekuensinya menjadi sulit memasuki fase-fase berikutnya, yaitu tahap transisi, apalagi tahap new normal. Jika tahap transisi gagal melaksanakan perubahan, maka kemungkinan akan masuk ke jurang kehancuran dan sangat sulit untuk kembali bangkit menuju tahap new normal, sedangkan jika berhasil menjalani tahap transisi tersebut, maka tidak absurd akan terjadi peningkatan yang sangat signifikan menuju tahap new normal. Oleh karena itu penulis memandang pentingnya menyiapkan dan mengatur tahap transisi seproduktif dan seefektif mungkin sebelum menjalani new normal, sebagaimana indikator yang telah disahkan oleh WHO dan pemerintah.

\section{Strategi Pembelajaran Di Masa Transisi New Normal}

Kontroversi masyarakat indonesia tentang pembukaan sekolah di masa transisi menuju new normal menjadi semakin menggema dan sangat dilematik, tentu ini memiliki argumentasi masing-masing. Salah satu alasan bagi masyarakat yang pro dengan pembukaan sekolah adalah karena kondisi kas sekolah yang semakin menipis, sehingga membutuhkan pemasukan untuk menggaji para guru, teristimewa sekolah swasta. Sedangkan yang memprotes, kebanyakan datang dari orang tua/wali siswa. Mereka takut karena walaupun sudah masuk pada transisi new normal, kasus Covid-19 belum sepenuhnya berhenti. Bahkan jika melihat kasus positif semakin meningkat karena dilakukannya test dan tracing yang luar biasa oleh pemerintah. (Fahmi Syahirul 2020).

Meniru dari Inggris, Jerman dan Vietnam, mengutip dari detik health 04 Juni 2020, 3 negara tersebut telah memutuskan untuk kembali pada New Normal dan membuka sekolah, namun tetap mengikuti protokol kesehatan yang sangat ketat, seperti Lorong sekolah hanya dipakai satu arah saja, wajib pakai masker, Siswa di ruangan kelas dibatasi, waktu mengajar dibagi dua gelombang, Jarak kursi antara siswi satu dengan lainnya berjauhan sejauh 1,5 sampai 2 meter dan Jendela tetap dibuka untuk sirkulasi udara. (Nafilah Sri Sagita K 2020).

Plt Dirjen PAUD, Pendidikan Dasar dan Pendidikan Menengah Kemendikbud 
menjelaskan bahwa Jika tahun ajaran ditunda atau dimundurkan ke Januari 2021, ada beberapa dampak dan penyelarasan sehingga tahun ajaran tetap dilaksanakan pada pertengahan Juli 2020 dengan pola belajar berbasis daring atau bukan belajar tatap muka". (Tim PRMN 02 2020).

Menanggapi hal tersebut, Ikatan Dokter Anak Indonesia (IDAI) mengusulkan kepada pemerintah agar sekolah tetap ditutup dan belajar online (Ayunda Pininta Kasih 2020). Di era internet seluler, negara-negara di seluruh dunia telah melakukan berbagai upaya efektif dalam pendidikan online, tetapi pendidikan online lebih merupakan pelengkap bagi pendidikan sekolah, dan pendidikan online normal berskala besar tidak memiliki banyak kasus. Kampanye "School Out, But Class's On" diluncurkan oleh pemerintah Cina selama epidemi COVID-19 menciptakan aplikasi pendidikan online skala besar yang normal (Longjun Zhou et al 2020).

Pada tanggal 15 Juni 2020, Kementerian Pendidikan dan Kebudayaan, Kementerian Agama, Kementerian Kesehatan, dan kementerian dalam Negeri memutuskan untuk menyusun panduan penyelenggaraan pembelajaran pada tahun ajaran dan tahun akademik baru di masa COVID 19. Prinsip Kebijakan Pendidikan di Masa Pandemi COVID-19 dengan prinsip kebijakan bahwa kesehatan dan keselamatan peserta didik, pendidik, tenaga kependidikan, keluarga, dan masyarakat merupakan prioritas utama dalam menetapkan kebijakan pembelajaran. Adapun pola Pola pembelajaran pendidikan anak usia dini, pendidikan dasar dan pendidikan menengah yaitu ajaran baru 2020/2021 tetap dimulai pada bulan Juli 2020, untuk daerah yang berada di zona kuning, oranye, dan merah, dilarang melakukan pembelajaran tatap muka di satuan pendidikan, satuan pendidikan pada zona-zona tersebut tetap melanjutkan Belajar dari Rumah (Kemendikbud 2020). New normal di sektor pendidikan itu sangat berbeda dari sektor-sektor kehidupan lainnya, sehingga harus penuh siaga dan cermat (Nur Aini 2020).

Berdasarkan situasi tersebut, manajemen darurat umum menjadi solusi terbaaik. Inisiatif kebijakan darurat yang disebut "Suspending Classes Without Stopping Learning atau penangguhan kelas tanpa menghentikan pembelajaran" bertujuan untuk mengubah kegiatan pengajaran menjadi pengajaran online (Wunong Zhang et al 2020). Pembelajaran jarak jauh atau online telah menjadi norma (Samantha L. Schneider and Martha Laurin Council 2020). Pembelajaran online sangat dibutuhkan untuk mengimbangi perkembangan dunia pendidikan yang didukung oleh teknologi informasi yang mengarah ke era digital baik proses maupun konten di era revolusi industri 4.0. Dengan pembelajaran online, proses pembelajaran dapat terjadi di mana saja dan kapan saja secara fleksibel (Unung Verawardina et al 2020).

Pendidikan pada masa darurat ini perlu dibedakan dari periode normal. "penangguhan kelas tanpa menghentikan pembelajaran" mencerminkan pembelajaran dalam arti luas, yang 
tidak hanya merujuk pada pembelajaran terstruktur dari kurikulum sekolah, tetapi juga mencakup pembelajaran berbagai konten. Pembelajaran semacam itu dapat dilakukan dengan berbagai cara, yang tujuannya adalah untuk mendukung pertumbuhan siswa. Sementara itu, ditekankan bahwa pengetahuan pencegahan dan pengendalian epidemi perlu dimasukkan sebagai tambahan pada kurikulum nasional formal, dengan penekanan khusus pada mempopulerkan pengetahuan pencegahan epidemi, diekspresikan melalui kelas pendidikan kehidupan, pendidikan keselamatan publik dan pendidikan kesehatan mental (Zhang et al 2020).

Implementasi kebijakan adalah proses yang dinamis yang menghubungkan antara tujuan Dari semua langkah, sepatutnya civitas akademi, khususnya pihak sekolah, (kepala sekolah, guru dan orang tua) berkolaborasi untuk menerapkan sistem manajemen darurat publik yaitu sebuah prosedur yang memungkinkan pengambilan keputusan darurat dan sirkulasi informasi yang terpusat, dan sebuah sistem untuk manajemen kelas dan respons multilevel (Zhang et al 2020).

\section{Manajemen Sumber Daya Manusia (MSDM) dalam Meningkatkan Strategi Pembelajaran Di Era New Normal Transition}

Beberapa sekolah di Indonesia diliburkan guna mencegah penyebaran COVID 19, maka pihak yang sangat dirugikan adalah segenap civitas akademi, apabila sekolah diliburkan. Namun apabila dicermati secara akurat, siswa adalah pihak yang paling merasakan imbasnya. masalahnya, apabila pembelajaran terhenti atau diundur maka waktu pelaksanaan kegiatan belajar selama setahun akan mundur sampai batas waktu yang tidak ditentukan. Maka dari itu sangat diperlukan pendidikan yang berorientasi pada global relevant need yaitu kebutuhan yang relevan.

Untuk itu, pendidikan memerlukan sumberdaya yang handal, baik sumberdaya manusia maupun sarana prasarana bagi efisiensi pendidikan. Adanya Covid-19 telah mendorong guru dan tenaga akademik sekolah mengambil sejumlah kebijakan terkait dengan kegiatan pembelajaran. Sebagai personal yang terjun di dunia pendidikan, Faktanya, penulis melihat adanya dampak dari kebijakan belajar di rumah bagi siswa yang dimulai sejak bulan Maret ini. Agenda yang sudah terjadwal menjadi berantakan, sehingga mau tak mau lembaga pendidikan juga harus melakukan evaluasi kebijakan guna mengantisipasi dampak Covid 19 ini. Ujian Nasional yang ditiadakan, kemudian Ujian akhir sekolah yang harus diselenggarakan via WhatsApp merupakan salah satu perubahan yang dihadapi. Manajemen lembaga pendidikan harus mampu beradaptasi dengan pandemi ini dan dituntut agar tetap bisa menjalankan agenda 
rutin yang sudah terjadwal meski tetap menjaga sosial distanscing maupun psychical distanscing.

Ketika pembelajaran di lembaga pendidikan terhenti akibat wabah ini, maka dari itu opini publik terhadap lembaga pendidikan terutaa guru akan menjadi semakin positif. kaitannya dengan kompetensi professional maka guru harus menguasai

1. materi, struktur, konsep, dan pola pikir keilmuan yang mendukung pelajaran yang digajar.

2. Memahami standar kompetensi dan kompetensi dasar mata pelajaran/bidang pengembangan yang diajar.

3. Mengelaborasikan materi pembelajaran yang dimampu secara kreatif.

4. Menumbuhkan keprofesionalan secara berkelanjutan dengan melakukan tindakan instrospektif.

5. Mampu menggunakan TIK untuk berkomunikasi dan mengembangkan diri (Wakhudin Dkk 2020).

Berkali-kali disinggung di atas, bahwa sangat diperlukan kerja sama dan manajemen yang sudah terstruktur, baik itu guru, kepala sekolah dan orang tua wali untuk mampu menyajikan pembelajaran daring. Kepala sekolah dengan kedudukannya yang begitu strategis harus mampu menampilkan kepemimpinan yang efektif, manajemen sekolah yang baik harus disertai oleh guru baik, sehingga kurikulumnya dapat diterjemahkan menjadi pembelajaran yang baik. Keefektifan suatu sekolah dalam menggapai visi, mengemban misi, mememuni tujuan dan target, serta dalam menjalankan aktivitas pembelajaran mempersyaratkan adanya seorang kepala sekolah yang menampilkan kepemimpinan yang efektif (mbscenter 2016). Bentuk-bentuk manajemen sekolah antara lain: 


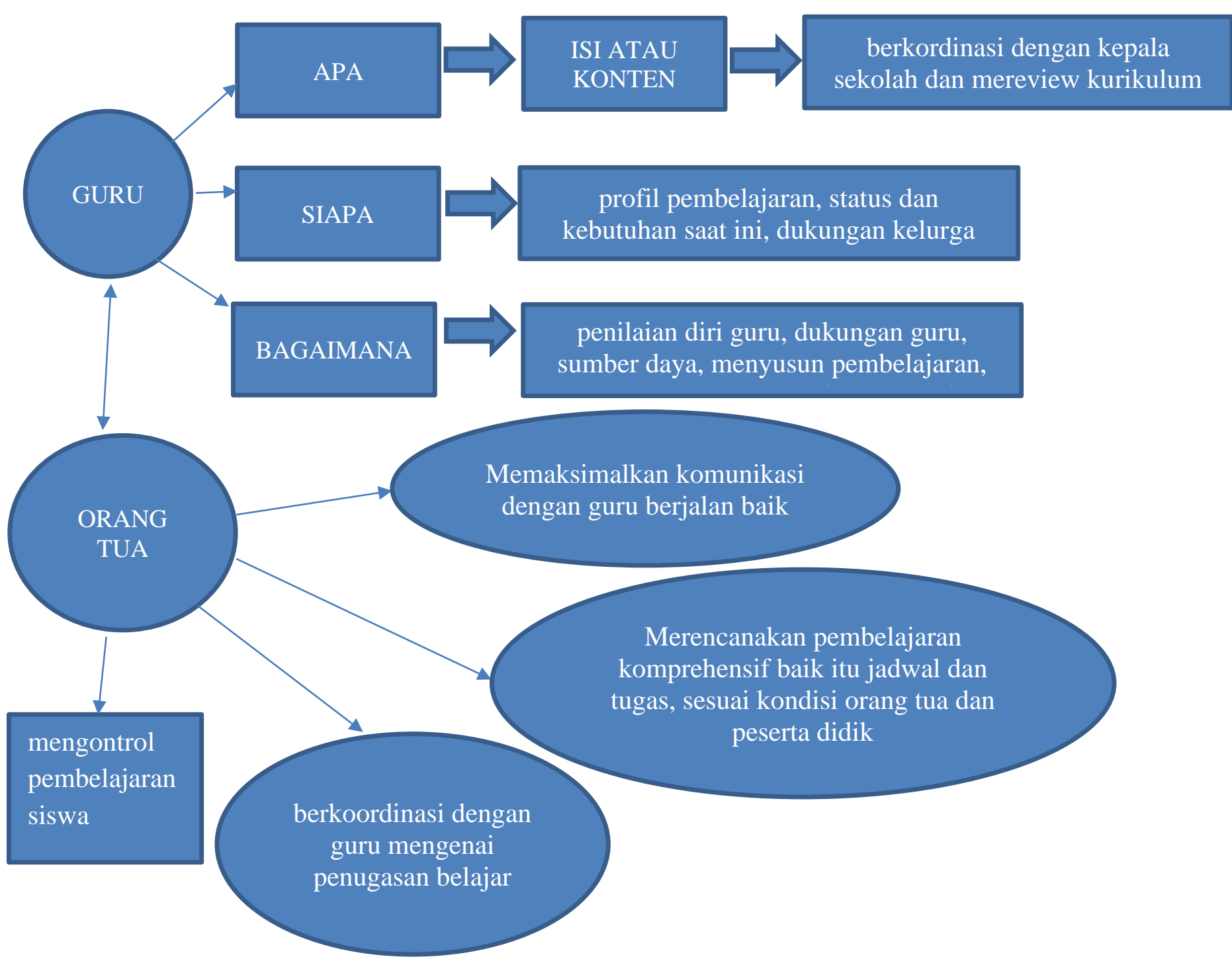

(guruberbagi.kemdikbud.go.id/ 2020)

\section{PENUTUP}

Manajemen SDM dalam meningkatkan strategi pembelajaran di era new normal adalah dengan upaya, kesiapan matang, pembekalan baik dari segi kecakapan TI dan keterbiasaan berlangsungnya virtual learnig. Mungkin pandemi adalah awal pencetus maraknya atau ditetapkannya aturan belajar online bagi siswa d Indonesia oleh Pemerintah dan Kemendikbud sendiri, walaupun sebelumnya sekolah-sekolah elite, bonafit sudah lebih dulu menginjakkan kaki belajar dengan memanfaatkan teknologi tetapi bisa dipastikan tidak terlalu mendominasi seperti sebelum pandemic terjadi. Untuk itu 2 elemen pokok berlangsung kegiatan belajarmengajar, siswa dan guru ini harus dibekali, mumpuni dan tau arah belajar yang akan filterisasi agar meminimalisir kesalahanpahaman antara guru dan siswa. Sementara siswa, di rumah, 
belajar dibantu dan diawasi oleh orangtuanya agar tidak terjadi tipu daya, kemalasan dan kecurangan saat pelaksanaan ujian. Sehingga etika, nilai/norma tetap dijunjung tinggi dalam dunia akademisi. Inilah strategi pembelajaran yang paling tepat dilakukan dalam era new normal ini Perubahan zaman yang begitu cepat, siap ataupun tidak harus diikuti oleh semua daerah jika tidak mau terbelakang. Terdapat perubahan dan tantangan besar yang akan di hadapi dengan tetap menjalankan aktivitas di tengah pandemi, tapi ini merupakan solusi. Dari sinilah siswa bisa belajar dengan situasi pandemi, dan tetap dimotivasi serta dibimbing guru untuk bisa sukses di masa mendatang. 


\section{DAFTAR PUSTAKA}

Ahmad, I. F. (2020). Asesmen Alternatif Dalam Pembelajaran Jarak Jauh Pada Masa Darurat Penyebaran Coronavirus Disease (Covid-19) Di Indonesia, Jurnal Pedagogik: 209.

Akib, H. (2012). Implementasi Kebijakan: Apa, Mengapa dan Bagaimana, Jurnal Ilmiah Ilmu Administrasi Publik. https://doi.org/10.26858/jiap.v1i1.289.

Aprilianto, A. (2019). Manajemen SDM. Yogyakarta: Bening Pustaka.

Albertus, A. (2020). edukasi.kompas.com. 26 Mei. Diakses Juli 07, 2020. https://edukasi.kompas.com/read/2020/05/26/152138171/ini-padanan-kata-new-normaldari-badan-bahasa-kemendikbud.

Aini, N. (2020). republika.co.id. 30 Juni. Diakses Juli 07, 2020. https://republika.co.id/berita/qcq1h5382/jokowi-ingatkan-daerah-tak-buru-buruterapkan-new-normal.

Butarbutar, P.E. (2020). www.kompasiana.com. 07 Juni. Diakses Juli 07, 2020. https://www.kompasiana.com/poltakbutarbutar8687/5edc7440d541df2e047dd2b3/newnormal-pada-sekolah.

Bardan, A.B . (2020). nasional.kontan.co.id. Disunting oleh Anna Suci Perwitasari. 20 Mei. Diakses Juli 07, 2020. https://nasional.kontan.co.id/news/pemerintah-siapkan-tigasyarat-penyesuaian-psbb.

CNN Indonesia. (2020). CNN Indonesia. 20 Mei. Diakses Juli 07, 2020. https://www.cnnindonesia.com/nasional/20200520133813-20-505287/tiga-syaratmenuju-the-new-normal-versi-epidemiolog-ui.

Darmalaksana, W. (2020) New Normal Perspektif Sunnah Nabi Saw. 1-5. http://digilib.uinsgd.ac.id/id/eprint/31093.

FKUI 2020. (2020). ocw.ui.ac.id. 2 Mei. Diakses Juli 08, 2020. https://ocw.ui.ac.id/course/view.php?id=75.

guruberbagi.kemdikbud.go.id/. (2020). https://guruberbagi.kemdikbud.go.id/.

Gragert, E, and Kakinda. (2011). A. Preparing Globally Competent Educators. In SITE 2011-Society for Information Technology \& Teacher Education International Conference.

Handoko, T. H. (1991). Manajemen. Yogyakarta: BPFF.

Harsono, F.H. (2020). www.liputan6.com/. 13 Mei. Diakses Juli 07, 2020. https://www.liputan6.com/health/read/4251622/survei-kpai-belajar-di-rumah-selamacovid-19-bikin-anak-stres-dan-lelah.

HM, J. (2017). Sistem Informasi Manajemen. Tangerang Selatan: Universitas Terbuka. 
Kristiono, N. (2020). www.minews.id. 20 Mei. Diakses Juli 07, 2020. https://www.minews.id/news/ini-pengertian-new-normal-versi-achmad-yurianto-2.

Kompas.com. (2020). www.kompas.com. 04 Juni. Diakses Juli 07, 2020. https://www.kompas.com/edu/read/2020/06/04/220402871/new-normal-pendidikanyang-berorientasi-pada-siswa?page=all.

Kurniadi. (2020). Menyiapkan Pendidikan Menuju Normal Baru. 4 Juni. Diakses Juli 07, 2020. http://www.untan.ac.id/menyiapkan-pendidikan-menuju-normal-baru/.

Kartiko, A. (2019). Manajemen Mutu Pendidikan. Yogyakarta: Bening Pustaka.

Kemp, René, Derk Loorbach, and Jan Rotmans. (2007). Transition Management as a Model for Managing Processes of Co-Evolution towards Sustainable Development, International Journal of Sustainable Development and World Ecology. https://doi.org/10.1080/13504500709469709.

Kasih, A.P. (2020). www.kompas.com. 31 Mei. Diakses Juli 07, 2020. https://www.kompas.com/edu/read/2020/05/31/061839671/ikatan-dokter-anakanjurkan-sekolah-tidak-dibuka-sampai-desember-2020.

Maharani, E. (2018). www.republika.co.id. 04 Desember. Diakses Juli 08, 2020. https://www.republika.co.id/berita/pendidikan/eduaction/18/12/03/pj60ej335kemendikbud-hanya-40-persen-guru-siap-dengan-teknologi.

mbscenter. (2016). www.mbscenter.or.id. 04 April. Diakses Juli 09, 2020. http://www.mbscenter.or.id/site/page/id/459/title/Penguatan\%20Manajemen\%20Pendidi kan\%20Persekolahan\%20Dalam\%20Rangka\%20Menghasilkan\%20Sumber\%20Daya\% 20Manusia\%20Di\%20Era\%20Kompetisi\%20Global.

Merdeka.com. (2020). www.merdeka.com. 17 Juni. Diakses Juli 07, 2020. https://www.merdeka.com/peristiwa/sekolah-di-era-new-normal-guru-dituntut-ubahkonsep-pembelajaran.html.

Muslih, B. (2020). Urgensi Komunikasi dalam Menumbuhkan Motivasi di Era Pandemi Covid19, Jurnal Penelitian Manajemen Terapan (PENATARAN), 60.

Nasution, M. N. (2015). Manajemen Mutu Terpadu. Bogor: Ghalia Indonesia.

Nastitie, D.P. (2020). kompas.id. 3 Mei. Diakses Juli 08, 2020. https://kompas.id/baca/humaniora/ilmu-pengetahuan-teknologi/2020/05/03/gurudituntut-kreatif-dan-melek-teknologi/.

Paul M, M. (2012). BUKU PEDOMAN COVID-19. Psychology Applied to Work: An Introduction to Industrial and Organizational Psychology, Tenth Edition Paul. 
https://doi.org/10.1017/CBO9781107415324.004.

Putsanra, D.V. 2020. tirto.id. 16 Maret. Diakses Juli 08, 2020. https://tirto.id/daftar-e-learningkemendikbud-sekolah-online-untuk-mencegah-corona-eFrR.

2020. en.unesco.org. 20 Mei. Diakses Juli 2020. https://en.unesco.org/covid19/educationresponse.

Prem, K., Yang Liu, Timothy W. Russell, Adam J. Kucharski, Rosalind M. Eggo, Nicholas Davies, Stefan Flasche, et al. (2020). The Effect of Control Strategies to Reduce Social Mixing on Outcomes of the COVID-19 Epidemic in Wuhan, China: A Modelling Study, The Lancet Public Health. https://doi.org/10.1016/S2468-2667(20)30073-6.

Praherdhiono, H. (2020). Implementasi Pembelajaran Di Era \& Pasca Pandemi Covid 19. 4. Malang Jawa Timur: CV Seribu Bintang.

Rotmans, J., and Derk Loorbach. (2009). Complexity and Transition Management, Journal of Industrial Ecology. https://doi.org/10.1111/j.1530-9290.2009.00116.x.

Rizqulloh, R. (2020). Artikel Review Tentang E-Learning Dan Pembelajaran Jarak Jauh (PJJ) Saat Masa Pandemi. 3.

Redaksi WE Online. (2020). www.wartaekonomi.co.id. Disunting oleh Muhammad Syahrianto. 20 Mei. Diakses Juli 07, 2020. https://www.wartaekonomi.co.id/read286402/6-syaratpenerapan-the-new-normal-dari-who-apa-saja.

Sagita K, N.S (2020). health.detik.com. 04 Juni. Diakses Juli 06, 2020. https://health.detik.com/berita-detikhealth/d-5039896/3-negara-sudah-mulai-bukasekolah-bagaimana-new-normal-diterapkan

Setiana, D. J. (2018). Manajemen dan Supervisi Pendidikan. Bandung: CV Pustaka Setia.

Sanjaya, R. (2018). New Normal Dalam Pendidikan Tinggi. Suara Merdeka. http://www.suaramerdeka.com/smcetak/detail/124756.

Schneider, S.L., and Martha Laurin Council. (2020). Distance Learning in the Era of COVID19, Archives of Dermatological Research. https://doi.org/10.1007/s00403-020-02088-9.

Shenoy, V., Sheetal Mahendra, and Navita Vijay. (2020). COVID 19 Lockdown Technology Adaption, Teaching, Learning, Students Engagement and Faculty Experience, Mukt Shabd Journal. https://doi.org/2347-3150.

Sneader, K., and Shubham Singhal. (2020). Beyond Coronavirus: The Path to the next Normal. McKinsey \& Company.

Suciati, S. (2020). Improvement Of Teacher Creativities and Initiatives Through Online Learning Models In The Covid-19 Pandemic Period, Ideguru: Jurnal Karya Ilmiah Guru 
5 (1). https://jurnal-dikpora.jogjaprov.go.id/index.php/jurnalideguru/article/view/131 .

Syahirul, F. (2020). rmoljabar.id. 15 Juni. Diakses Juli 06, 2020. https://rmoljabar.id/jalantengah-pembukaan-sekolah-di-era-new-normal/.

Tim COVID-19 Indonesia. (2020). Protokol Tatalaksana Covid-19.1.

Tim COVID-19. (2020). PDPI PERKI PAPDI PERDATIN IDAI.. Protokol Tatalaksana Covid19. 1 .

Tim Jurnal Presisi. (2020). jurnalpresisi.pikiran-rakyat.com. 31 Mei. Diakses Juli 07, 2020. https://jurnalpresisi.pikiran-rakyat.com/nasional/pr-15391633/prediksi-jusuf-kalla-newnormal-akan-dijalani-minimal-tiga-tahun.

Tim PRMN 02. (2020). www.pikiran-rakyat.com. 29 Mei. Diakses Juli 06, 2020. https://www.pikiran-rakyat.com/pendidikan/pr-01390597/kemendikbud-tegaskan-tahunajaran-baru-tidak-mundur-ke-januari-2021.

Tsinghua Tongfang Knowledge Network Technology. (2006). http://en.cnki.com.cn. http://en.cnki.com.cn/Article_en/CJFDTotal-ZWGD200604007.htm.

Verawardina, U., Lise Asnur, Arina Luthfini Lubis, Yeka Hendriyani, Dochi Ramadhani, Ika Parma Dewi, Resmi Darni, Tigus Juni Betri, Wilda Susanti, and Titi Sriwahyuni. (2020). Reviewing Online Learning Facing the Covid-19 Outbreak, Talent Development and Excellence.

Vintoko. (2020). wow.tribunnews.com. Disunting oleh Atri Wahyu Mukti. 30 Mei. Diakses Juli 07, 2020. https://wow.tribunnews.com/2020/05/30/pakar-epidemiologi-ui-ungkapwaktu-yang-tepat-untuk-memulai-new-normal-tunggu-dulu.

Wakhudin Dkk. (2020). Covid-19 Dalam Ragam Tinjauan. Edited by Didik Haryadi Santoso dan Awan Santosa. Cetakan Pe. D.I. Yogyakarta: MBridge Press.

Winarsih, R. d. (2016). Manajemen Pelayanan: Pengembangan Model Konseptual, Penerapan Citizen's Charter dan Standar Pelayanan Minimal. Yogyakarta: Pustaka Pelajar. Wakhudin Dkk. (2020). “COVID-19 DALAM RAGAM TINJAUAN.” 68. Yogyakarta: MBridge Press.

$\begin{array}{lllllll}\text { Wikipedia. (2020). id.wikipedia.org. } 01 \text { Juli. Diakses Juli } & 06,202 .\end{array}$ https://id.wikipedia.org/wiki/Kenormalan_baru.

Wijoyo, H, and Irjus Indrawan. (2020). Model Pembelajaran Menyongsong New Era Normal Pada Lembaga Paud Di Riau, Jurnal Sekolah Universitas Negeri Medan, 4 (3): 205-12. https://doi.org/https://doi.org/10.24114/js.v4i3.18526. 
Warsono, T. d. (2020). Birokrasi Baru Untuk New Normal: Tinjauan Model Perubahan Birokrasi Dalam Pelayanan Publik Di Era Covid-19, Dialogue Jurnal Ilmu Administrasi Publik, 6.

Zhang, W., Yuxin Wang, Lili Yang., and Chuanyi Wang. (2020). Suspending Classes Without Stopping Learning: China's Education Emergency Management Policy in the COVID-19 Outbreak, Journal of Risk and Financial Management. https://doi.org/10.3390/jrfm13030055.

Zhao, Y. (2010). Preparing Globally Competent Teachers: A New Imperative for Teacher Education, Journal of Teacher Education. https://doi.org/10.1177/0022487110375802. Zhou, L., Shanshan Wu, Ming Zhou, and Fangmei Li. (2020). School's Out, But Class' On', The Largest Online Education in the World Today: Taking China's Practical Exploration During The COVID-19 Epidemic Prevention and Control As an Example, SSRN Electronic Journal. https://doi.org/10.2139/ssrn.3555520. 